\title{
PERSONAL SUPPORT NETWORKS AS MODERATORS IN DYADIC EMPLOYEE-SUPERVISOR RELATIONSHIPS
}

\author{
FRANK W. HAGER \\ Dipl.-Wirt.-Ing. (FH), MBA, M.A. \\ NORBERT G. BRINK \\ Dipl.-Ing, Dipl.-Ing. (FH)
}

\begin{abstract}
Health-promoting management behaviour and the associated social support require professional and social competences of supervisors. The behaviour of leaders has an impact on motivation, commitment, as well as on the mental and physical health of their employees - and consequently on their ability to work and employability. Thus, from an entrepreneurial point of view, the skill of managers to provide adequate social support is an indispensable prerequisite for the economic success of the organisation. The two-way relationship (dyad) between the leader and the led, as a reciprocal, dynamic negotiation process, is in the focus of this investigation. For this research in the field of social support, the functions and effects of personal, social support networks have been considered. The question arises, as to whether they can compensate or moderate inadequate social support from supervisors and its effects on the employee's state of health. From a differential view, social support networks can be understood as a matrix, providing the infrastructure for the production and distribution of a broad spectrum of social support benefits, which in turn represent the social resources of an employee - an important factor for her/his physical and mental health. Social resources in the form of social relationships and social interactions can help to cope with workloads and to better master challenges. In stressful situations, it is helpful to receive emotional or practical support from the support networks of the primary environment. The sample comprises of managers in middle management $(\mathrm{N}=132)$ from different German automotive suppliers. In the examination, the Survey of Perceived Supervisor Support (SPSS), the Short Form Health Survey (SF-36) and the Evaluation of Social Systems Scale (EVOS) has been used. It was postulated that the quality of social support networks (mirrored by the EVOS-dimensions "quality of relationships" and "self-efficacy") moderate the relationship between perceived supervisor support and employees self-rated health. Partly, significant correlations between perceived supervisory support and the self-rated health dimensions "emotional well-being", "energy/fatigue" and "role limitations due to personal or emotional problems" could be determined. It was also possible to gain the important insight that the networking of employees outside the official hierarchical structures plays an essential role in coping with stress.
\end{abstract}


Keywords: Germany, perceived supervisor support, self-rated health, social support networks

JEL code: M12, J24, J28

\section{INTRODUCTION}

In this work, the focus is on the social support provided by the supervisor. Inversely, in the case of a positive evaluation, the superior in a dyadic relationship receives an increased degree of loyalty from his or her employee, more commitment to the organisation's goals and a greater willingness to take on duties and unpleasant tasks. ${ }^{1}$ According to the relevant literature from support research and a veritable flood of research reports in this field, it is assumed in this article that especially dyadic employee-supervisor relationships initiate a process of mutual investment in professional activity in which the development potential of interpersonal relationships is exploited. This results in a significantly higher team performance, which goes far beyond the basic performance and makes a decisive contribution to team success. ${ }^{2}$

Whether employees cooperate and show the aforementioned loyalty depends largely on their leadership behaviour and the quality of the provided social support, whether they function as a resource and whether they are perceived as such by employees. Thus, executives who perform little or no management duties, focus unilaterally on the achievement of goals rather than on the needs of employees, exercise strong control, withhold information or deal with destructively, represent less as a resource than a burden. ${ }^{3}$ Studies confirm the link between social supervisor support and sick leave as well as early retirement. ${ }^{4}$ In conclusion, supervisor support has a positive influence on stress perception ${ }^{5}$, exhaustion ${ }^{6}$, job

Lewicka, D., Glinska-Newes, A., Morrow, D. L., \& Gorka, J. (2018). The effect of job characteristics on employee loyalty: the mediation role of vertical trust and perceived supervisor support. Marketing and Management of Innovations, 2, p. 169. Rousseau, V., \& Aubé, C. (2010): Social Support at Work and Affective Commitment to the Organization: The Moderating Effect of Job Resource Adequacy and Ambient Conditions, The Journal of Social Psychology, 150(4), pp. 321-340.

2 Bierhoff, H.-W. (2006). Sozialpsychologie. Stuttgart: Kohlhammer, p. 471. Rousseau, V., \& Aubé, C. (2010). Social Support at Work and Affective Commitment to the Organization: The Moderating Effect of Job Resource Adequacy and Ambient Conditions, The Journal of Social Psychology, 150(4), pp. 321-340.

3 Stummer, H. (2007). Entsolidarisierung von Führungsverhalten und mögliche Auswirkungen auf die Gesundheit.Industrielle Beziehungen: Zeitschrift für Arbeit, Organisation und Management, 14(3), pp. 270-278.

4 Stadler, P., Spieß, E. (2004). Mitarbeiterorientiertes Führen und soziale Unterstützung am Arbeitsplatz. Grundzüge und Beispiele eines Informations- und Handlungskonzepts. Bundesanstalt für Arbeitsschutz und Arbeitsmedizin, Dortmund, p. 10.

5 Cohen, S., \& Wills, T. A. (1985). Stress, social support, and the buffering hypothesis. Psychological Bulletin, 98(2), pp. 310-357.

6 Leiter, M., \& Maslach, C. (1988). The impact of interpersonal environment on burnout and organizational commitment. Journal of Organizational Behavior, 9, pp. 297-308. 
satisfaction ${ }^{7}$ und mental health ${ }^{8}$ of the employees. If the led employee evaluates supervisor support as deficient, a need for help is perceived and she/he decides to ask others from support networks for help as part of a coping strategy. ${ }^{9}$

After the model in this study, affected employees will first consult close persons in the work area or the organisation and try to activate their knowledge, experience, advice, and assessments and possibly also their active support to solve their problem. If these efforts are not successful, for example, if the nature of the problems requires more specific knowledge, empathy, trust, etc. than is available in the primary social support networks, help is sought outside these boundaries. People in the primary support network are displaced by those who can provide more targeted support in problem situations. In a quasicentrifugal movement out of the primary environment, people are contacted who are increasingly distant, less familiar or emotionally close. According to this view, professionals are the last link in a chain of help request activities, which is reached when the help request appears unsuccessful to both previous instances. Hence, in the course of the help search process, a successive expansion of the personal support network would take place due to increasingly specialised persons; at the same time, a decrease in the emotional closeness or familiarity with the network members would be expected. The question arises as to whether private support networks (primary and secondary environment) can compensate for deficient social support of the supervisor and its negative effects on the health status of employees. Against the background of this mechanism it is believed, the health benefits of the primary environment's support networks are higher, in the case of the emergence of a compensation.

Due to the emotional closeness and familiarity in the primary environment, not only the quality of the relationship was considered as a possible compensating (moderating) variable in the collection of the data, but also self-efficacy with the supporting network members.

In general, the localisation and precise classification of social support networks are difficult, as they can only be defined and located through the subjective perception of an individual. A recording of social networks through different structural characteristics (e.g. scope, frequency of contacts, density, distance, homogeneity, heterogeneity or social participation $)^{10}$, which is common in network research, was not possible due to the quantitative research approach. The model of hierarchical compensation suggested by Cantor (1979) assumes the existence

Adams, J., Claus, A., Claus, M. et al. (2018). Soziale Unterstützung und Arbeitszufriedenheit - Unterschiede zwischen verschiedenen Tätigkeitsbereichen. Präventive Gesundheitsförderung, 13, pp. 18-23.

8 Kienle, R., Knoll, N., \& Renneberg, B. (2006). Soziale Ressourcen und Gesundheit: Soziale Unterstützung und dyadisches Bewältigen. In: Renneberg, B., Hammelstein, P. (Eds) Gesundheitspsychologie. Berlin, Heidelberg: Springer, pp. 107-117.

9 Die gesunde Arbeit. Berlin: De Gruyter, p. 120. Rudow (2014) distinguishes two support systems in the workplace: supervisor support and peer (co-worker) support.

10 Diewald, M. (1990). Soziale Beziehungen - Verlust oder Liberalisierung? Soziale Unterstützung in informellen Netzwerken. Berlin: Edition Sigma, pp. 102-105. 
of different preference orders, which largely determine to whom a person would turn in the case of an urgent need for help or a problem. In essence, this model states that preference for certain supporters depends primarily on the nature of the relationship, but is largely independent of the type of support provided. In general, relatives - especially partners and children - would be regarded as the most appropriate supporters in the individual value system, followed by extrafamilial relationships such as friends and, most recently, formal organisations or professional supporters. Thus, in this study, the targeted selection of the support networks was based on the theoretical significance of Cantor (1979) and was categorised in "work colleagues", "family" and "friends". The networks were precisely defined in the first paragraph and evaluated by the individual based on a questionnaire.

The hypotheses below were tested by correlation analysis, a linear regression and a moderator analysis. The sample is adequate with $\mathrm{N}=132$, but not representative. Greater test strength and results that are more valid could be achieved with a larger number of participants. It is also unclear whether the results in other industries and job-profiles are comparable to those obtained in this research.

\section{SOCIAL SUPPORT NETWORKS}

According to Jansen (1999), social networks can generally be defined as a set of nodes "[...] connected by a set of relations." Actors, represented by nodes, are therefore connected by relationships (edges) between them. Edges represent the relationship of the nodes to each other. The relationship between two nodes can be, for example, a personal knowledge, a kinship, a friendship or a formal relationship. ${ }^{11}$ As already mentioned, a social network can be understood as a kind of matrix that is responsible for the distribution of social support. To an extent, social networks are structural prerequisites for receiving social support. ${ }^{12}$ The characteristics of formal and informal networks are describing the involvement of an individual in structurally and content wise different network structures with different actors. ${ }^{13}$

However, this equates the (general) concept of a network with functions of social relationships - in particular with social support in the sense of support resources and support networks. One variant of this form of use, which can also

11 Jansen, D. (1999). Einführung in die Netzwerkanalyse: Grundlagen, Methoden, Anwendungen. Opladen: Leske und Budrich, p. 53. Siehe diesbezüglich auch Keupp, H. (1987). Soziale Netzwerke. Eine Metapher des gesellschaftlichen Umbruchs? In: Röhrle, B. \& Keupp, H.: Soziale Netzwerke. Frankfurt: Campus, p. 12: "Menschen werden als Knoten dargestellt, von denen Verbindungsbänder zu anderen Menschen laufen, die wiederum als Knoten symbolisiert werden."

12 Berkman, L, \& Glass, T. (2000). Social Integration, Social Networks, Social Support, and Health. In: Kawachi, I. (Ed.) (2000): Social Epidemiology. Oxford: University Press, pp. 137-173.

13 Ibarra, H. (1993). Personal Networks of Women and Minorities in Management: A Conceptual Framework. The Acadamy of Management Review, p. 58. 
be problematised, assumes a theoretically and conceptually broader definition of the term as a personal or egocentric network and operationalises it via the concept of social support. From an empirical point of view, this form of use leads to the same restriction as a functional definition of the term. ${ }^{14}$ As can easily be seen, the definition of (personal) support networks is problematic. For this investigation, therefore, a separate derivation and definition of the term must take place. In this article, a social support network is understood as a specific section and subset of the personal network (generally defined as the private web of social relationships), from which an individual has received one or more forms of social support - or, if their subjective assessment is taken as a basis - believes to receive it when needed. In general, according to Röhrle (1987), in this context, one could also apply the terms of sectors or zones since support networks are normatively defined subunits of networks and/or personal networks. ${ }^{15}$ There are two reasons for this differentiation: On the one hand, personal social networks contain not insignificant parts of "neutral" relationships, that do not provide any kind of support. It is also argued by Lairaiter (2008) that a social network does not only consist of supporting individuals.

If search strategies are used as a survey criterion, only about one-third to onehalf of the members of a personal network is perceived as supportive or designated as such. Accordingly, personal networks include not only supportive, but also indifferent, non-supporting, as well as stressful and conflictual relationships. ${ }^{16}$ Petzold \& Märtens (2013) also concluded that personal networks should not be valued exclusively positive and as a component of personal resources. It should also be considered that social relationships and thus egocentric networks are multifunctional. This additionally prohibits equating them with a function (e.g. social support). ${ }^{17}$ Consequently, the term support network must be clearly distinguished from a general (personal) social network term in the further course of this work.

The definition of support networks used for this research and their composition is extremely important, because the quantification of relevant investigation characteristics in the design of the questionnaire and its evaluation is aimed at ensuring the comparability of the data and making the statistical evaluation procedures accessible with regard to possible comparisons and dependencies.

14 Lairaiter, A.-R. (2008). Soziales Netzwerk in der Psychologie. Forum Gemeindepsychologie, 13(1), München: Deutsches Jugendinstitut. URL: http://www.gemeindepsychologie.de/fg-1-2008_06.html Last accessed: 18.03.2019.

15 Röhrle, B. (1987). Soziale Netzwerke und soziale Unterstützung. Befunde und Rezeptionsvarianten eines "neuen" Konzepts in der Psychologie. Heidelberg: Universität, Psychologisches Institut, p. 21.

16 Lairaiter, A.-R. (2008). Soziales Netzwerk in der Psychologie. Forum Gemeindepsychologie, 13(1), München: Deutsches Jugendinstitut. URL: http://www.gemeindepsychologie.de/fg-1-2008_06.html.

17 Petzold, H., \& Märtens, M. (2013). Wege zu effektiven Psychotherapien. Wiesbaden: Springer VS, p. 19 \& 198, bezugnehmend auf Wellman, B. (1982). Studying Personal Communities. In: Marsden, P. V., \& Lin, N. (Eds.), Social Structure and Network Analysis, Beverly Hills: Sage, p. 79. 
The classification and definition of the support networks for this study will be carried out below.

Colleagues are support sources with a high degree of availability for employees. The support benefits depend on the quality of the relationship in the individual case. ${ }^{18}$ In a team, a department, etc. different characters meet, who have to work together daily. As a result, there are different relationships between individual colleagues or characters. Henderson \& Argyle (1985) distinguish four different types of working relationships: [1] rather intimate, [2] positive but superficial, [3] indifferent (neutral) and [4] negative. ${ }^{19}$ As already mentioned, due to the empirical research design and considering the higher sample size, not all network characteristics could be systematically and individually collected for each individual employee. The interviewees themselves determined how their colleagues or network members should be classified in the respective specified support network and regarding the quality of their relationships. The authors assume that colleagues who see themselves on a daily basis and also talk about private matters (and not just about professional matters) "know each other well" (network-density). This study focuses on the close and trusted relationships according to Henderson \& Argyle (1985) since they are most relevant for the quality of a support network (a measure of relationship strength). In the introduction (instruction) of the respective question battery, the strength of the relationship between the network members was explicitly asked. The instructions for the question battery support network "colleagues" are as follows:

"In the following, your work colleagues are in focus. If there are trusted people in your organisation with whom you maintain a close, trusting relationship and receive social support through them, how would you rate the quality of this support network? Please answer the following questions."

After relationships based on partnership, the family has the greatest supportive importance. ${ }^{20}$ By their nature, family relationships are permanent, which is essential, both for the willingness to provide help and for their acceptance and success. Lack of reciprocity has less of an impact on the current relationship design, as it can be restored in the long term because there is a perception that some other person in the relationship system has already made comparable inputs for oneself in the past or one can expect it in the future if needed. ${ }^{21}$

$18 \mathrm{Haß}, \mathrm{W}$. (2002). Soziale Unterstützungsnetzwerke von Menschen mit chronischer Polyarthritis - Eine explorative, netzwerkanalytische Studie. Dissertation. Köln: Wirtschafts- und Sozialwissenschaftlichen Fakultät, Universität Köln, p. 53. URL: https://kups.ub.uni-koeln.de/683/1/11v4582.pdf.

19 Henderson, M. \& Argyle, M. (1985). Social support by four categories of work colleagues: Relationship between activities, stress and satisfaction. Journal of Occupational Behavior, 6, pp. 229-239.

20 Diewald, M. (1990). loc. cit., p. 107.

21 Ibid., p. 108. 
After the partnership, parents and children occupy the most important position in this ranking, followed by siblings and finally other relatives. Diewald (1990) speaks of a "hierarchical structure concerning normative solidarity obligations." Overall, regular interactions and shared life experiences also shape the individual significance of individual kinships (also beyond the family's core) and can further enhance the perceived quality of support. In this study, "family" is to be understood as the core that comprises a few selected relatives of both parents (bilaterally). The support network is part of the social system "entire family" and consists only of preferred relatives with whom the person actively maintains relationships, is in close contact and receives social support. Because a person's support network involves both, some family members of the mother and the father (patrilateral and matrilateral), not all members of the person's support network are related to all others, but all are closely or remotely related to the person. For this investigation, it is irrelevant whether members of the person's support network live in different places, meet regularly, or whether the support network is composed of one or both lineage groups. ${ }^{22}$ The question battery "family" was introduced as follows:

"Please think now of your close family circle and of those family members with whom you maintain close, trusting relationships and receive social support through them. How would you rate the quality of this support network? Please answer the following questions."

According to Diewald (1990), friendships are "[...] primarily important for sociability, for conveying recognition and appreciation, for acquiring new competencies and orientations, for conveying norms and information, as well as for motivational support." They are not as strongly characterised by rules and obligations as relationships within a family, but they are characterised by a freedom of design. This means that they must be maintained or renewed in a permanent process. ${ }^{23}$ Friendships protect against the feeling of isolation, ${ }^{24}$ they strengthen self-esteem ${ }^{25}$ and convey the feeling of being personally accepted ${ }^{26}$, especially because friendships, unlike kinships, arise through free election, and their very

22 The lineage group consists only of the close blood relatives of the mother or the father and forms an effective social unit.

$23 \mathrm{Haß,} \mathrm{W.} \mathrm{(2002).} \mathrm{Soziale} \mathrm{Unterstützungsnetzwerke} \mathrm{von} \mathrm{Menschen} \mathrm{mit} \mathrm{chronischer} \mathrm{Polyarthritis} \mathrm{-} \mathrm{Eine}$ explorative, netzwerkanalytische Studie. Dissertation. Köln: Wirtschafts- und Sozialwissenschaftlichen Fakultät, Universität Köln, p. 52 referring to Beck, Ulrich (1986): Die Risikogesellschaft. Auf dem Weg in eine andere Moderne. Frankfurt: Suhrkamp.

24 Laursen, B., Bukowski, W. M., Aunola, K. and Nurmi, J. (2007). Friendship Moderates Prospective Associations Between Social Isolation and Adjustment Problems in Young Children. Child Development, 78, pp. 1395-1404.

25 Keefe, K., \& Berndt, T. J. (1996). Relations of Friendship Quality to Self-Esteem in Early Adolescence. The Journal of Early Adolescence, 16(1), pp. 110-129.

26 Bishop, J. A., \& Inderbitzen, H. M. (1995). Peer Acceptance and Friendship: An Investigation of their Relation to Self-Esteem. The Journal of Early Adolescence, 15(4), pp. 476-489. 
existence thus enables the individual to feel socially attractive. ${ }^{27}$ On the one hand, friendships are much more sensitive to asymmetries in interactions (e.g. social recognition). Support from them is more strongly linked to the principle of reciprocity than from families. On the other hand, friends are more likely than relatives to contribute to life satisfaction. In addition, they have proven to be particularly important for emotional support and leisure activities. They are often consulted as trusted persons in life decisions. Accordingly, it was found empirically that friends are obviously preferred to relatives. And while the former tends to refer more to professionals, relatives seem to offer more lay solutions. ${ }^{28}$ The instruction of the question battery "friends" within the questionnaire was initiated as follows:

"Now focus on your close friends with whom you maintain close, trusting contacts and receive social support through them. How would you rate the quality of this support network? Please answer the following questions."

\section{HYPOTHESES}

[1] There are significant correlations between the SF-36 (physical and mental health dimensions) and Perceived Supervisor Support. The personal support-networks [2] "colleagues", [3] "family and [4] "friends" will moderate this relationship. [5] The health-promoting effect of support networks from the primary environment can be rated higher than that of support networks in the secondary environment due to their emotional proximity to the network members.

\section{METHODOLOGY}

A cross-sectional survey design has been used to determine the desired research results. The data has been collected by the recruitment of employees in different German industries and branches, online on XING-Network ${ }^{29}$. The online survey has been conducted via the platform "SoScisurvey" ${ }^{30}$. The participants received no incentives.

To measure Perceived Supervisory Support, the SPSS scale (Kottke \& Sharafinski, 1988) has been used. ${ }^{31}$ The SPSS scale is based on the Perceived

\footnotetext{
27 Rapsch, A. (2004). Soziologie der Freundschaft: Historische und gesellschaftliche Bedeutung von Homer bis heute. Stuttgart: Ibidem, p. 110.

28 Haß, W. (2002). loc. cit., p. 52.

29 https://www.xing.com/

30 https://www.soscisurvey.de/

31 Kottke, J. L., \& Sharafinski, C. (1988). Measuring perceived supervisory and Organizational Support. Educational and Psychological Measurement, 48, pp. 1075-1079.
} 
Organizational Support Survey by Eisenberger et al. (1986) ${ }^{32}$ - with one difference - all items refer to the supervisor, not to the organisation as a global entity. Given that the definitions of Perceived Organisational Support and Perceived Supervisory Support are practically identical in nature, their measurements have been adapted to accommodate these similarities. The SPSS consists of 16 items with a 7-point Likert scale anchored from "strongly disagree (1) to "strongly agree" (7). Example items include: "My supervisor really cares about my well-being." "My supervisor is willing to help me when I need a special favour." "My supervisor tries to make my job as interesting as possible." The items "If my supervisor could hire someone to replace me at a lower salary, he/she would do so." and "If given the opportunity, my supervisor would take advantage of me." must be reversed during summation of the total values. Higher scores indicate that participants perceived their supervisors to be more supportive. Cronbach's alpha in the present study was measured at .912 .

The EVOS-scale can be used to assess of relationship quality and collective effectiveness in multi-person systems. The EVOS has two subscales, consisting of four and five items. There is also a final consensus item. Example of subscale "quality of relationship": "For me, the way we talk to each other, is...". Examples of subscale "collective efficacy": "For me, the way we decide what needs to be done, is...". Members of the social system answer the questionnaire with help of a 4-point rating scale. The format is ranging from "very poor" (0) to "very good" (3). The answers of the consensus item "I think we will give similar answers to this questions" range from "strongly disagree" to "strongly agree". The consensus item is not an integral part of the scale and may be left out (as in this study). The answers to the items of the two subscales are added (without consensus item) to a total score [8], [14]. Cronbach's alphas for the subscales in the present study were measured at ,811 for quality of relationship, and ,829 for collective efficacy.

The SF-36 (v.1.0) is a general health questionnaire that consists of 36 questions. It allows statements about the individual's state of health by means of 8 different dimensions. It makes statements about: [1] general health perceptions 5 questions, [2] physical functioning - 10 questions, [3] role limitations due to physical health problems - 4 questions, [4] bodily pain - 2 questions, [5] energy/ fatigue - 4 questions, [6] emotional well-being - 5 questions, [7] role limitations due to personal or emotional problems - 3 questions, [8] Social functioning 2 questions. For the evaluation of the SF-36 Questionnaire v1.0, all answers are first recoded into predetermined points using a recoding table. The average score of all questions of the respective health dimension is then calculated so that 8 average scores are obtained for the 8 dimensions. These 8 scores describe the patient's state of health in their respective dimensions, which can be assessed using comparison tables. The possible score ranges from 0 to 100 points. 0 points represent the greatest possible restriction of health, while

32 Eisenberger, R., Huntington, R., Hutchinson, S., \& Sowa, D. (1986). Perceived organizational Support. Journal of Applied Psychology, 71, pp. 500-507. 
100 points represent the absence of health restrictions. In this study the internal consistency (Cronbach's $\alpha$ ) for the scale physical functioning was .831 , the role limitations due to physical health problems .814, the scale bodily pain .843 , the scale general health perceptions .804 , the scale energy/fatigue. 817 , the scale social functioning .867 , the scale role limitations due to personal or emotional problems .910 and the scale mental well-being .881 .

\section{RESULTS}

The sample represents a subset of the population of all employees in middle management in Germany. It was necessary to exclude 3 individuals from the sample, $2(0.3 \%)$ for error in the age record and $1(0.1 \%)$ for not responding more than $50 \%$ of the SF-36 items, totalling 132 participants with data available for analysis. The age of the participants ranges from 20 to 59 years $(M=37.12, S D=13.34)$. The authors found no normal distribution for the age of the interviewees, as the specified significance limit for this study falls far short of $\mathrm{p}<.050 .67$ participants $(50.76 \%)$ are male and 65 females $(49,24 \%)$. Table 1 presents the results from the correlation analysis between Perceived Supervisor Support and the eight SF-36 health dimensions.

Table 1

Pearson Correlation (Perceived Supervisor Support and the eight SF-36 health dimensions)

\begin{tabular}{|l|c|}
\hline & $\begin{array}{c}\text { perceived supervisor } \\
\text { support }\end{array}$ \\
\hline physical functioning & .012 \\
\hline bodily pain & -.023 \\
\hline role limitations due to physical health problems & $.034^{*}$ \\
\hline role limitations due to personal or emotional problems & $-.234^{* *}$ \\
\hline emotional well-being & $.312^{* *}$ \\
\hline social functioning & .101 \\
\hline energy/fatigue & $.344^{* *}$ \\
\hline general health perceptions & $.074^{*}$ \\
\hline
\end{tabular}

** Correlation is significant at the 0.01 level (2-tailed)

* Correlation is significant at the 0.05 level (2-tailed)

Since the correlation analysis shows no significant interactions worth mentioning in all SF-36 physical and mental health dimensions and Perceived Supervisor Support, the first hypothesis is rejected. Accordingly, no correlation could be measured between the individual health dimensions of the SF-36 questionnaire (physical functioning, bodily pain, role limitations due to 
physical health problems, social functioning and general health perceptions) and perceived supervisor support. Significant correlations were found in the factors "role limitations due to personal or emotional problems", "emotional well-being" and "energy/fatigue."

Table 2 shows the results of the Pearson correlation between EVOS dimensions "quality of relationship"/"collective efficacy" and the eight SF-36 health dimensions for all participants.

Table 2

Pearson Correlation (EVOS dimensions "quality of relationship"/"collective efficacy" and the eight SF-36 health dimensions)

\begin{tabular}{|l|c|c|c|c|c|c|}
\hline & $\begin{array}{c}\text { quality of } \\
\text { relationship } \\
\text { "colleagues" }\end{array}$ & $\begin{array}{c}\text { collective } \\
\text { efficacy } \\
\text { "colleagues" }\end{array}$ & $\begin{array}{c}\text { quality of } \\
\text { relationship } \\
\text { "family" }\end{array}$ & $\begin{array}{c}\text { collective } \\
\text { efficacy } \\
\text { "family" }\end{array}$ & $\begin{array}{c}\text { quality of } \\
\text { relationship } \\
\text { "friends" }\end{array}$ & $\begin{array}{c}\text { collective } \\
\text { efficacy } \\
\text { "friends" }\end{array}$ \\
\hline $\begin{array}{l}\text { physical } \\
\text { functioning }\end{array}$ & .058 & -.012 & .056 & .034 & .011 & .022 \\
\hline bodily pain & .011 & $.053^{*}$ & -.013 & $.110^{*}$ & -.027 & .080 \\
\hline $\begin{array}{l}\text { role } \\
\text { limitations } \\
\text { due to } \\
\text { physical } \\
\text { health } \\
\text { problems }\end{array}$ & -.045 & .045 & -.049 & $.091^{*}$ & .015 & -.024 \\
\hline $\begin{array}{l}\text { role } \\
\text { limitations } \\
\text { due to } \\
\text { personal or } \\
\text { emotional } \\
\text { problems }\end{array}$ & $-.310^{*}$ & $-.189^{*}$ & $-.216^{*}$ & $-.272^{* *}$ & $-.124^{*}$ & $-.156^{*}$ \\
\hline $\begin{array}{l}\text { emotional } \\
\text { well-being }\end{array}$ & $.332^{* *}$ & $.328^{* *}$ & $.220^{*}$ & $.189^{* *}$ & $.199^{* *}$ & $.189^{*}$ \\
\hline $\begin{array}{l}\text { social } \\
\text { functioning }\end{array}$ & -.027 & .043 & $.102^{*}$ & .067 & -.021 & .043 \\
\hline $\begin{array}{l}\text { energy/ } \\
\text { fatigue }\end{array}$ & $.324^{* *}$ & $.302^{* *}$ & $.156^{* *}$ & $.201^{* *}$ & -.057 & .110 \\
\hline $\begin{array}{l}\text { general health } \\
\text { perceptions }\end{array}$ & $.121^{*}$ & $.081^{*}$ & -.021 & .114 & .037 & -.019 \\
\hline
\end{tabular}

** Correlation is significant at the 0.01 level (2-tailed)

${ }^{*}$ Correlation is significant at the 0.05 level (2-tailed)

The hypothesis that the health-promoting effect of support networks from the primary environment can be rated higher than that of support networks in the secondary environment due to their emotional proximity to the network members was rejected. There are no significant correlations between SF-36 dimensions and the support networks "friends" and "family". There are only 
significant correlations with the support network "colleagues" from the secondary environment.

Next, a linear regression analysis was calculated for the three significant dimensions of self-rated health in Table 1 and "perceived supervisor support" as the constant.

Table 3

Regression Analysis - Model Summary

\begin{tabular}{|l|c|c|c|c|}
\hline & $\mathbf{R}$ & $\mathbf{R}^{2}$ & Adj. R & $\begin{array}{c}\text { Std. Error of } \\
\text { the Estimate }\end{array}$ \\
\hline $\begin{array}{l}\text { role limitations due to personal or emotional } \\
\text { problems }\end{array}$ & $.234^{\mathrm{a}}$ & .055 & .051 & 1.178 \\
\hline emotional well-being & $.312^{\mathrm{a}}$ & .097 & .092 & 1.245 \\
\hline energy/fatigue & $.344^{\mathrm{a}}$ & .118 & .112 & 1.341 \\
\hline
\end{tabular}

a. Predictors: (Constant) Perceived Supervisor Support

According to the Cohens (1988) classification ${ }^{33}$, the determination coefficients "emotional well-being" and energy/fatigue" correspond to a medium effect. The determination coefficient "role limitations due to personal or emotional problems" corresponds to a weak effect.

A separate linear regression analysis was calculated for the three significant dimensions of self-rated health in Table 2 and the EVOS Subscales "quality of relationship" and "collective efficacy" for the three support-networks "colleagues", "family" and "friends". For reasons of space and clarity, Table 4 shows only the determination coefficients $\mathrm{R}^{2}$ in the form of a matrix.

Table 4

Regression Analysis - $\mathbf{R}^{2}$-values

\begin{tabular}{|l|c|c|c|c|c|c|}
\hline \multicolumn{1}{|c|}{ Predictors } & $\begin{array}{c}\text { quality of } \\
\text { relationship } \\
\text { "colleagues" }\end{array}$ & $\begin{array}{c}\text { collective } \\
\text { efficacy } \\
\text { "colleagues" }\end{array}$ & $\begin{array}{c}\text { quality of } \\
\text { relationship } \\
\text { "family" }\end{array}$ & $\begin{array}{c}\text { collective } \\
\text { efficacy } \\
\text { "family" }\end{array}$ & $\begin{array}{c}\text { quality of } \\
\text { relationship } \\
\text { "friends" }\end{array}$ & $\begin{array}{c}\text { collective } \\
\text { efficacy } \\
\text { "friends" }\end{array}$ \\
\hline $\begin{array}{l}\text { role limitations } \\
\text { due to personal } \\
\text { or emotional } \\
\text { problems }\end{array}$ & .096 & .036 & .047 & .074 & .015 & .024 \\
\hline $\begin{array}{l}\text { emotional well- } \\
\text { being }\end{array}$ & .110 & .108 & .048 & .035 & .040 & .036 \\
\hline energy/fatigue & .105 & .091 & .024 & .040 & .003 & .012 \\
\hline
\end{tabular}

33 According to the author, there is a strong effect at $\mathrm{R}^{2} \geq .25$, a medium effect at $\mathrm{R}^{2} \geq .09$ and a weak effect at $\mathrm{R}^{2} \geq .01$. 
In the regression analysis (Table 4), a medium-strong effect was determined for the support network "colleagues" in its two EVOS dimensions "quality of relationship" and "collective efficacy" for the outcome variables "emotional wellbeing" and "energy/fatigue". The same applies to the EVOS dimension "quality of relationship" for the outcome variable "role limitations due to personal or emotional problems". For the EVOS dimensions of the other two support networks "family" and "friends", only a weak effect could be determined for the outcome variables.

According to ANOVA, the regression of the models makes a statistically significant prediction (Sig. .000 $\leq .050)$. Finally, surprisingly no significant effects of the SF-36 dimensions were associated with gender. Emotional well-being was positively associated with job tenure $(\beta=.192 ; \mathrm{p}<.05)$.

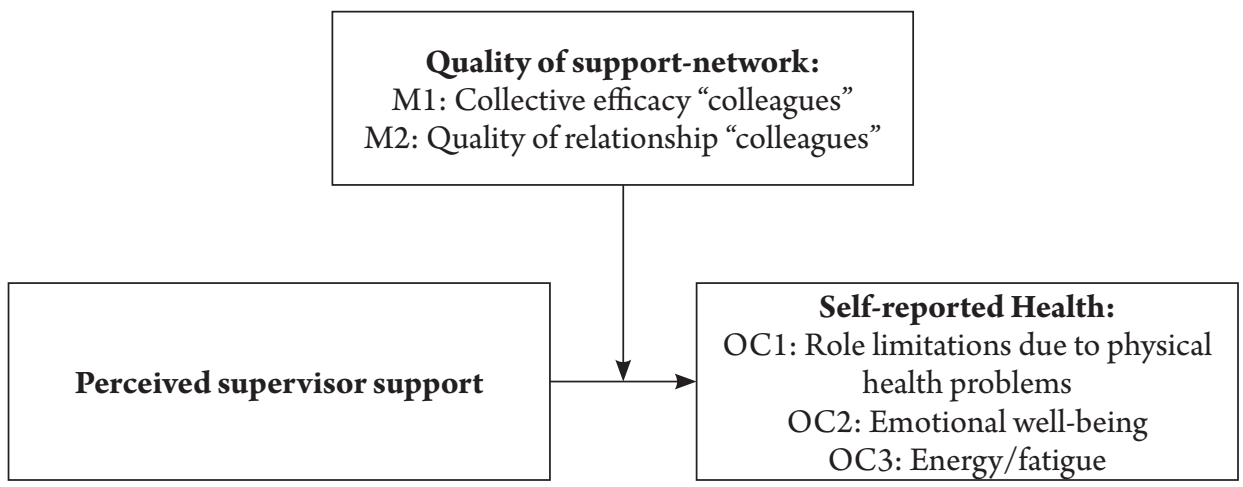

Figure 1. Model of the moderator analysis. $\mathrm{M}=$ Moderator variable, $\mathrm{OC}=$ Outcome variable

Source: author's construction

The prerequisite for the moderator analysis, the normal distribution of the dependent variable and the moderator variable, is given. The previous correlation analysis in Table 1 shows, that perceived supervisory support has a significant influence in the SF-36 factors "role limitations due to personal or emotional problems", "emotional well-being" and "energy/fatigue"

A moderator analysis (Table 5) should check the role of the Support Networks "quality of relationship "colleagues" and collective efficacy "colleagues" as a possible moderator between Perceived Supervisor Support and SF-36s' significant three dimensions (Table 1). The reason for choosing Support Network "colleagues" is the $\mathrm{R}^{2} \geq .09$ according to Cohens (1988) classification. All weak predictors have been dropped.

This indirect effect was tested for significance using the bootstrapping procedures outlined by Hayes (2018). Bootstrapping uses random sampling with replacement to increase accuracy in sampling estimates. The PROCESS macro, 
model 4, was used to test the model. This analysis used 5,000 bootstrap samples created from the original sample to estimate bias-corrected standard errors and 95\% confidence intervals for the indirect effect of perceived supervisor support on health outcomes via support networks (Table 5).

Table 5

Results of the Moderator Analysis

\begin{tabular}{|l|l|l|}
\hline & $\begin{array}{l}\text { quality of relationship } \\
\text { "Colleagues" }\end{array}$ & $\begin{array}{l}\text { collective efficacy } \\
\text { "Colleagues" }\end{array}$ \\
\hline $\begin{array}{l}\text { Relationship: perceived supervisor support } \\
\text { on role limitations due to personal or } \\
\text { emotional problems }\end{array}$ & $-.551 / 1.045 \mathrm{p}<.037$ & $-.341 / 1.645 \mathrm{p}<.057$ \\
\hline $\begin{array}{l}\text { Relationship: Perceived supervisor support } \\
\text { on emotional well-being }\end{array}$ & $-1.359 /-.459 \mathrm{p}<.001$ & $-1.211 /-.261 \mathrm{p}<.001$ \\
\hline $\begin{array}{l}\text { Relationship: perceived supervisor support } \\
\text { on energy/fatigue }\end{array}$ & $-1.113 /-.879 \mathrm{p}<.001$ & $-1.659 /-.255 \mathrm{p}<.001$ \\
\hline
\end{tabular}

As described by Hayes (2018) indirect effects are considered significant at $\mathrm{p}<.050$ if zero is not included in the $95 \%$ confidence interval. ${ }^{34}$ The results in Table 5 show a moderating effect of the EVOS dimensions "quality of relationship" and "collective efficacy" of the support network "colleagues" on both SF-36 dimensions "emotional well-being" and "energy/fatigue". Hypotheses 3 and 4 are rejected.

\section{DISCUSSION}

The present study aimed at finding out in a first step, whether there are significant correlations between Perceived Supervisor Support and Self-rated psychological and physical health. The hypothesis that all eight dimensions of the SF-36 questionnaire correlate significantly with Perceived Supervisor Support had to be rejected. For better clarity and understanding, these eight subcategories could have been combined into a physical (PCS = physical component summary) and a mental (MCS = mental component summary) summation scale. However, this approach was deliberately omitted, since from the author's point of view "energy/fatigue" and "general health perceptions", as well as "social functioning" cannot be assigned one hundred percent to both sum scales, and thus there would be a danger of generating fewer meaningful mixed categories. As the results show, this distinction was rightly made, since the individual correlations "role limitations due to personal or emotional problems", "emotional well-being" and "energy/fatigue" with the dependent variable "perceived supervisor support" are

34 Hayes, A. F. (2018). Partial, conditional, and moderated mediation: Quantification, Inference, and Interpretation. Communication Monographs, 85. London: Taylor \& Francis, pp. 4-40. 
stronger than the respective correlations with the two mixed categories and thus details could be better worked out.

Following the ICD classification system ${ }^{35}$ and focusing on the research results for the diagnosis of burnout syndrome since the mid-1970s, then the most important validated test procedures show which symptoms are used to operationalise the burnout syndrome today. These symptoms have intersections with the three previously mentioned individual dimensions of SF-36. Maslach (1982) describes the burnout syndrome based on criteria, such as "emotional exhaustion" "depersonalisation" and "professional efficacy". Emotional exhaustion results from excessive emotional or physical effort (tension). It is the stress dimension of burnout syndrome. Those affected feel weak, powerless, tired and dull. They suffer from weakness of drive and are easily irritable. ${ }^{36}$ A study by Fradelos et al. (2014) confirms these connections: "The "Emotional Exhaustion" subscale of the Maslach Burnout Inventory (MBI) appears to be strongly and negatively correlated with the "Energy/Fatigue" $(\mathrm{R}=-0.658, \mathrm{p}=0.000)$ and "Emotional Well-Being" $(\mathrm{R}=-0.675, \mathrm{p}=0.000) .{ }^{37}$ With the reaction of the depersonalisation, the concerned individual establishes a distance between him or herself and his or her clients (patients, pupils, persons in need of care, customers, etc.). This manifests itself in an increasing indifference and sometimes cynical attitude towards them. The work becomes an impersonal routine. Again, Fradelos et al. (2014) found a correlation between the subscale of the MBI "Depersonalization" with "Emotional Well-being" $(\mathrm{R}=-0.543, \mathrm{p}=0.000)$ and "Energy/Fatigue" $(\mathrm{R}=-0.462, \mathrm{p}=0.000){ }^{38}$ It becomes clear that the SF-36 dimensions "Emotional Well-Being" and "Energy/Fatigue" reflect this burnout (stress) dimension (partially) and are also predicted by Perceived Supervisor Support (Table 3).

This makes it clear how strongly professional life is shaped by the demands of employees are faced with on a daily basis and which are of importance to them - demands made on employees from outside or which they make on themselves. As long as employees judge their external and personal resources to be sufficient for meeting these requirements, they perceive them positively as challenges. If they judge their resources (including the support of superiors) to be insufficient to cope satisfactorily with the requirements, stress arises. In this study, everything indicates that mental health was initially affected by stress caused by poor support from the supervisor, which could lead to burnout symptoms. "Role Limitations due to personal or emotional Problems" is another value that correlates significantly with "perceived supervisor support" (Table 1).

35 The ICD is the global health information standard for mortality and morbidity statistics.

36 Maslach, C. (1982). Burnout: The Cost of Caring. Englewood Cliffs: Prentice Hall.

37 Fradelos, E., Tzitzikos, G., Giannouli, V., Argyrou, P., Vassilopoulou, C., \& Theofilou, P. (2014). Assessment of Burn-Out and Quality of Life in Nursing Professionals: The Contribution of Perceived Social Support. Progress in Health Sciences, 4(1), p. 107.

38 Fradelos, E., Tzitzikos, G., Giannouli, V., Argyrou, P., Vassilopoulou, C., \& Theofilou, P. (2014). loc. cit., p. 107. 
This factor of SF-36 indicates the extent to which emotional problems affect work or other daily activities. It is only a weakly correlating value. While the regression analysis shows, that "Perceived Supervisor Support" is a significant predictor of "Role Limitations due to personal or emotional Problems", the strength of the regression coefficient is weak $\left(\mathrm{R}^{2}=.055, \mathrm{p}=0.01\right)$. The results underline the importance of social support as a relief and protection factor with direct effect (main-effect hypothesis) on the stress perception of employees.

Basically this finding is not a novelty, because assumptions on the effect of social support are typically closely linked to models of stress development and stress management. The evaluation of a situation as acceptable, irrelevant or potentially negative depends on the individually available resistance resources, which include the available social resources. In addition, the mobilization of social support is also part of the adaptive stress management strategies. ${ }^{39}$

In a further step it was examined, whether the quality of social support networks - both in "personal" spheres (family, relatives \& friends) and in "organisational" spheres (colleagues) - influences the relationship between "perceived supervisor support" and the SF-36 dimensions "Emotional wellbeing", "energy/fatigue" and "role limitations due to personal or emotional problems" At this point, it is interesting to note that the EVOS subscales Quality of Relationship "Colleagues" and collective efficacy "colleagues" has the strongest and significant correlations and proved to be significant predictors, with the SF36 dimensions "Emotional Well-Being" und "energy/fatigue". This suggests that preferably colleagues have an influence on the mental health of an employee. In this context, the emotional closeness to the respective supporter ${ }^{40}$ or to the members of the support network may play a less important role than the same understanding of the supporter for the deficient work situation.

The results of the moderator analysis show that poor supervisor support can be better handled, to some extent, by employees, if they develop or maintain good quality work relationships and a sense of cohesion. A community that holds together and maintains a trusting team climate, thus can (partially) compensate this leader deficit. The same is for the team efficiency: Effective teams are convinced that they will succeed. This, in turn, motivates them to work harder. Small successes increase self-confidence and motivate the team to improve their technical and interpersonal skills through training. The higher these skills become, the greater the self-confidence and the ability to confirm the trust. If this condition is prevalent in the group, the team is able to compensate for poor

\footnotetext{
39 Hager, F. W., \& Seibt, T. (2018). Team Relationship Quality - A Moderator between Supervisor Support and perceived Stress. Proceedings of the $10^{\text {th }}$ CER Comparative Research Conference - International Scientific Conference for PhD Students of EU Countries, 10(2), London: Sciemcee Publishing, p. 15.

40 It cannot be assumed that every collegial relationship is a close friendship at the same time.
} 
supervisory support (for a limited time). For executives, therefore, team efficacy should be seen as an important factor that has to be changed for the better. ${ }^{41}$

\section{CONCLUSION}

A supervisor cannot always prevent stressful phases. However, he or she can prevent stressful situations by increasing self-efficacy and team (relationship) quality. The more the individual team members are aware of their self-efficacy, the more the group benefits - and the team can function well even in stressful times where the supervisor is limited or unavailable. Executives are therefore obliged to support team members identifying their responsibilities in day-today business and to increase their self-confidence in order to be more optimistic and self-confident in their future tasks and challenges. It is necessary that employees' achievements, as well as learning experiences, are reflected and tools for influencing the environment, as well as the distancing are made tangible. In the context of team development processes, the effects of action and behaviour on colleagues can be identified to create an improved team climate. ${ }^{42}$ Another goal of supervisors is the continuous improvement of the cohesion and relationship quality within their team. Communication should be meaningful and demanding. This aim includes the necessity that team members trust each other enough to exchange suggestions and to express ideas on their own. Strong communication within the team is a prerequisite, without it, the potential a team could achieve under other circumstances would suffer. Not only the potential, but as this study shows, also employee's health is suffering from a lack of relationship quality among colleagues. Even if this is not necessarily the focus of teambuilding measures: Emotions are of great importance for the development of mental strength and interpersonal relationships - and thus for the health of the company's social capital. Hence, supervisors should invest more time in expanding their (emotional) support skills in promoting the emotional attachment among teammates, enhancing climate and cohesion among their subordinates.

\section{REFERENCES}

Adams, J., Claus, A., Claus, M. et al. (2018). Soziale Unterstützung und Arbeitszufriedenheit - Unterschiede zwischen verschiedenen Tätigkeitsbereichen. Präventive Gesundheitsförderung, 13, pp. 18-23.

Berkman, L, \& Glass, T. (2000). Social Integration, Social Networks, Social Support, and Health. In: Kawachi, I. (Ed.) (2000). Social Epidemiology. Oxford: University Press, pp. 137-173.

Bierhoff, H.-W. (2006). Sozialpsychologie. Stuttgart: Kohlhammer.

${ }^{41}$ Hager, F. W., \& Seibt, T. (2018). loc. cit., p. 16.

42 Ibid. 
Bishop, J. A., \& Inderbitzen, H. M. (1995). Peer Acceptance and Friendship: An Investigation of their Relation to Self-Esteem. The Journal of Early Adolescence, 15(4), Beverly Hills: Sage, pp. 476-489.

Cohen, J. (1988). Statistical Power Analysis for the Behavioral Sciences. New York: Erlbaum.

Diewald, M. (1990). Soziale Beziehungen - Verlust oder Liberalisierung? Soziale Unterstützung in informellen Netz-werken. Berlin: Edition Sigma, pp. 102-105.

Fradelos, E., Tzitzikos, G., Giannouli, V., Argyrou, P., Vassilopoulou, C., \& Theofilou, P. (2014). Assessment of Burn-Out and Quality of Life in Nursing Professionals: The Contribution of Perceived Social Support. Progress in Health Sciences, 4(1), pp. 102-109.

Hager, F. W., \& Seibt, T. (2018). Team Relationhip Quality - A Moderator between Supervisor Support and perceived Stress. Proceedings of the 10th CER Comperative Research Conference - International Scientific Conference for PhD Students of EU Countries, 10(2), pp. 12-16, London: Sciemcee Publishing.

$\mathrm{Haß,} \mathrm{W.} \mathrm{(2002).} \mathrm{Soziale} \mathrm{Unterstützungsnetzwerke} \mathrm{von} \mathrm{Menschen} \mathrm{mit} \mathrm{chronischer}$ Polyarthritis - Eine explorative, netz-werkanalytische Studie. Dissertation. Köln: Wirtschafts- und Sozialwissenschaftlichen Fakultät, Universität Köln, URL: https://kups.ub.uni-koeln.de/683/1 /11v4582.pdf.

Hayes, A. F. (2018). Partial, conditional, and moderated moderated mediation: Quantification, inference, and interpretation. Communication Monographs, 85. London: Taylor \& Francis, pp. 4-40.

Henderson, M. \& Argyle, M. (1985). Social support by four categories of work colleagues: Rela-tionship between activities, stress and satisfaction. Journal of Occupational Behavior, 6, pp. 229-239.

Ibarra, H. (1993). Personal Networks of Women and Minorities in Management: A Conceptual Framework. The Acada-my of Management Review, pp. 56-87.

Jansen, D. (1999). Einführung in die Netzwerkanalyse: Grundlagen, Methoden, Anwendungen. Opladen: Leske und Budrich.

Keefe, K., \& Berndt, T. J. (1996). Relations of Friendship Quality to Self-Esteem in Early Adolescence. The Journal of Early Adolescence, 16(1), Beverly Hills: Sage, pp. 110-129.

Keupp, H. (1987). Soziale Netzwerke. Eine Metapher des gesellschaftlichen Umbruchs? In: Röhrle, B., \& Keupp, H.: Soziale Netzwerke. Frankfurt: Campus.

Kienle R., Knoll N., \& Renneberg B. (2006). Soziale Ressourcen und Gesundheit: Soziale Unterstützung und dyadisches Bewältigen. In: Renneberg, B., Hammelstein, P. (Eds) Gesundheitspsychologie. Berlin, Heidelberg: Springer, pp. $107-117$.

Lairaiter, A.-R. (2008). Soziales Netzwerk in der Psychologie. Forum Gemeindepsychologie, 13(1), München: Deutsches Jugendinstitut. URL: http://www. gemeindepsychologie.de/fg-1-2008_06.html. Last accessed: 18.03.2019.

Laursen, B., Bukowski, W. M., Aunola, K., and Nurmi, J. (2007). Friendship Moderates Prospective Associations Between Social Isolation and Adjustment Problems in Young Children. Child Development, 78(4), Chichester: Wiley, pp. 1395-1404.

Leiter, M., \& Maslach, C. (1988). The impact of interpersonal environment on burnout and organizational commitment. Journal of Organizational Behavior, 9, pp. 297-308.

Lewicka, D., Glinska-Newes, A., Morrow, D. L., \& Gorka, J. (2018). The effect of job characteristics on employee loyalty: the mediation role of vertical trust and 
perceived supervisor support. Marketing and Management of Innovations, 2, pp. $168-185$.

Maslach, C. (1982). Burnout: The Cost of Caring. Englewood Cliffs: Prentice Hall.

Maslach, C., \& Leiter, M. P. (2007). Burnout - Definition and Assessment A Mediation Model of Burnout and Engagement Implications for Interventions. Fink, G. (Ed.) Encyclopedia of Stress. Amsterdam: Elsevier, pp. 368-371.

Petzold, H., \& Märtens, M. (2013). Wege zu effektiven Psychotherapien. Wiesbaden: Springer VS.

Rapsch, A. (2004). Soziologie der Freundschaft: Historische und gesellschaftliche Bedeutung von Homer bis heute. Stuttgart: Ibidem.

Rousseau, V., \& Aubé, C. (2010). Social Support at Work and Affective Commitment to the Organization: The Moderating Effect of Job Resource Adequacy and Ambient Conditions, The Journal of Social Psychology, 150(4), pp. 321-340.

Röhrle, B. (1987). Soziale Netzwerke und soziale Unterstützung. Befunde und Rezeptionsvarianten eines neuen Konzepts in der Psychologie. Heidelberg: Universität Heidelberg, Psychologisches Institut.

Rudow (2014). Die gesunde Arbeit. Berlin: De Gruyter.

Stadler, P., Spieß, E. (2004). Mitarbeiterorientiertes Führen und soziale Unterstützung am Arbeitsplatz. Grundzüge und Beispiele eines Informations- und Handlungskonzepts. Bundesanstalt für Arbeitsschutz und Arbeitsmedizin, Dortmund.

Stummer, H. (2007). Entsolidarisierung von Führungsverhalten und mögliche Auswirkungen auf die Gesundheit.Industrielle Beziehungen. Zeitschrift für Arbeit, Organisation und Management, 14(3), pp. 270-278.

Wellman, B. (1982). Studying Personal Communities. In: Marsden, P. V., \& Lin, N. (Eds.), Social Structure and Network Analysis, Beverly Hills: Sage. 